\title{
Life after Trafficking: A gap in the UK's modern slavery efforts
}

Kate Roberts

Please cite this article as: K Roberts, 'Life after Trafficking: A gap in UK's modern slavery efforts, AntiTrafficking Review, issue 10, 2018, pp. 164-168, www.antitraffickingreview.org

The Modern Slavery Act (2015) was a symbol of the UK's commitment to combatting exploitation and human trafficking. Yet the Act offers little help to people who have been trafficked to, or in, the UK to recover and build a new life.

A recent report of the National Audit Office on public spending for reducing modern slavery states that although the UK has in place an identification and support system (the National Referral Mechanism, or NRM), 'The Home Office has no assurance that victims are not trafficked again, potentially undermining the support given through the NRM'. ${ }^{2}$

The UK government does not plan or enable needs-based support for trafficked people to rebuild their lives, or even collect any data on outcomes for trafficked people, including those who have been through its identification and support systems. On the contrary, its reluctance to guarantee even a year-long recovery period undermines those individuals' attempts to build a life after trafficking.

In $2016,3,805$ potential victims were referred to the NRM, a $17 \%$ increase on $2015 .{ }^{3} 1,075$ of those referred received a positive decision. ${ }^{4}$ A negative trafficking decision does not mean someone was not trafficked, but simply that there was not enough evidence to make a positive decision at that time. No pathways are put in place to protect those with a negative decision from further exploitation; nor is there data as to the current situation of those who have received a positive decision. Any information is piecemeal and largely anecdotal. When the Human Trafficking Foundation attempted to follow up with 73 survivors who had lost support, 18 were not contactable and completely unaccounted for. ${ }^{5}$ City Hearts, a safe house for survivors, found that $76 \%$ of a sample of clients who exited its services between 2011 and 2015 could not be contacted. ${ }^{6}$

For the majority, there is no ongoing specialist support after the official decision as to whether they have been trafficked or not. ${ }^{7}$ At present, if the decision is negative, support ends within 48 hours. If it is positive, support ends after fourteen days. In October 2017, the government announced that it would extend the exit deadlines to 45 days following a positive decision and nine days following a negative decision. ${ }^{8}$ The date for the change

1 National Crime Agency, National Referral Mechanism, NCA, 2015, retrieved 13 January 2018, http://www.nationalcrimeagency.gov.uk/about-us/what-we-do/specialist-capabilities/uk-human-traffickingcentre/national-referral-mechanism.

2 National Audit Office, 'Reducing Modern Slavery', December 2017, Summary, para 19.

3 National Crime Agency, National Referral Mechanism Statistics_End of Year Summary 2016, NCA, 2017, p. 1, retrieved 13 January 2018, http://www.nationalcrimeagency.gov.uk/publications/national-referral-mechanism-statistics/2016-nrmstatistics/788-national-referral-mechanism-statistics-end-of-year-summary-2016/file.

4 V Atkins, Response to a parliamentary question asked by Carolyn Harris MP, HC Deb, 12 December 2017, retrieved 8 March 2018, https://www.theyworkforyou.com/wrans/?id=2017-1122.115169.h\&s=national + referral + mechanism $+1075 \# \mathrm{~g} 115169 . \mathrm{r} 0$.

5 S Ferrell-Schweppenstedde, Day 46: Is there life after the safe house for survivors of modern slavery?, Human Trafficking Foundation, 2016, p. 9.

6 A Balch, Fresh Start: Integrating survivors of modern slavery, University of Liverpool, 2017, p. 8, retrieved 30 September 2017, https://www.liverpool.ac.uk/media/livacuk/csis/Fresh,Start,A5.pdf.

7 Some NGOs offer specialist ongoing support through charitable funds but there is no national coverage or capacity for everyone who has been through the NRM.

8 Home Office and Sarah Newton MP, 'Modern Slavery Victims to Receive Longer Period of Support', GOV.UK, 26 October 2017, retrieved 13 January 2018, https://www.gov.uk/government/news/modern-slavery-victims-to-receivelonger-period-of-support. 
has not yet been announced. While an improvement, these time frames for ending support are still unrealistically short. It makes no sense that recognised victims of such a serious and debilitating crime lose their support with no guarantee of even short-term basic needs such as secure immigration status and accommodation. This point has been described as a "cliff edge' and does much to undermine the trust of trafficked people, as well as to expose them to destitution or further exploitation.

I've been treated worse than an animal. I was given a positive trafficking decision and then not offered accommodation, even animals get shelter. ${ }^{10}$

In March 2017, a coalition of NGOs and lawyers published a policy document with recommendations to 'highlight the minimum standards needed for a sustainable support system towards recovery for adult survivors of slavery'. ${ }^{11}$ The document calls for a positive decision from the NRM to carry status which is of practical assistance to the recipient in rebuilding their life, and recommends that the decision should equate to a meaningful rehabilitation period provided through the issuing of a residence permit for a minimum time period of at least 12 months'. It also recommends that all potential victims be offered legal advice and representation as early in their identification as possible, and that each individual with a positive decision should be assigned a case worker who coordinates their care plan and access to services and is prepared to advocate on their behalf.

On 30 April 2017, the UK Parliament's Work and Pensions Select Committee published its report on victims of modern slavery. ${ }^{12}$ It found that victims were becoming destitute or even re-trafficked after a positive identification, due to a lack of understanding and recognition of their situation. The committee found that the sudden removal of support helped to explain the low convictions of traffickers, since victims were not supported to disclose their abuse and to testify. Giving evidence to the inquiry, Baroness Butler-Sloss described the NRM process as producing no result except 'a piece of paper' for victims. ${ }^{13}$

The committee found the government's response to its recommendations disappointing: 'The recommendation of granting one year's leave to remain to confirmed victims of slavery was rejected on the questionable grounds that it could increase immigration by providing incentives to pose as a victim'. ${ }^{14}$ Thus, immigration concerns appear to trump the UK government's professed commitment to upholding victims' rights.

Many survivors are involved in complex legal cases, which can include a compensation claim, a police investigation or criminal claim against their trafficker, plus any immigration applications. They are also likely to be dealing with medical and mental health issues and beginning to come to terms with what has happened to them. It can take years for survivors to disclose some of the details of their abuse. It is unrealistic to expect any kind of meaningful reflection and recovery, let alone active pursuit of justice, while an individual still has basic needs such as food and accommodation unmet and does not have even short-term security in the UK.

In April 2017 the Co-op, a cooperative business, launched its Bright Future programme, which offers survivors a paid work placement with a non-competitive interview at the end of it. ${ }^{15}$ In late 2017 the Co-op reported that one of the Bright Future participants had recently been named employee of the month for their store-a real

9 City Hearts, Integration Support Programme: Interim Report, January-March 2017, City Hearts, 2017, retrieved 8 March 2018 , http://city-hearts.co.uk/wp-content/uploads/2017/05/ISP-Interim-Report-J-M2017.pdf.

10 Survivor quoted in Ferrell-Schweppenstedde.

11 Human Trafficking Foundation et al., Supporting Adult Survivors of Slavery to Facilitate Recovery and Reintegration and Prevent Reexploitation, 2017, $\quad$ retrieved $\quad 8 \quad$ March 2018 , http://www.humantraffickingfoundation.org/sites/default/files/Long $\% 20$ term $\% 20$ survivor $\% 20$ support $\% 20$ needs $\% 20$ March\%2017\%202.pdf.

12 Commons Select Committee, “Inexcusable” Lack of Support for Modern Slavery Victims', UK Parliament, 30 April 2017, retrieved 8 March 2018, https://www.parliament.uk/business/committees/committees-a-z/commonsselect/work-and-pensions-committee/news-parliament-2015/report-victims-modern-slavery-16-17.

13 House of Commons Work and Pensions Committee, Victims of Modern Slavery: Twelfth report of session 2016 - 17, 2017, p. 15, retrieved 8 March 2018, https://publications.parliament.uk/pa/cm201617/cmselect/cmworpen/803/803.pdf.

14 Letter from Frank Field MP, Chair of the Work and Pensions Select Committee to Theresa May, UK Prime Minister, 13 December 2017, retrieved 8 March 2018, http://www.parliament.uk/documents/commons-committees/work-andpensions/Correspondence/Letter-to-the-Prime-Minister-protection-for-victims-of-modern-slavery-13-12-17.pdf.

15 Co-op, Our Bright Future Programme, Co-operative Group Limited, 2017, retrieved 8 March 2018, https://www.cooperative.coop/ethics/bright-future. 
example of restoring dignity and contributing to society through work. ${ }^{16}$ This is a national model offering a pathway for building a life after trafficking. ${ }^{17}$ However, it is only open to survivors who have the right to work in the UK.

Lord McColl of Dulwich has tabled a Private Members Bill ${ }^{18}$ which calls for victim support beyond the NRM's trafficking finding - including a residence permit of at least one year and casework support during this time. These are minimum asks which would give trafficked people a chance of accessing justice in the form of a compensation claim, health services or education opportunities and, if they are ready, employment. However, even one year's leave with support to begin to build a life after trafficking is something the UK government has not yet supported. ${ }^{19}$ Until they do, trafficked people are left without these most basic of provisions, and the question of an 'ideal life' after trafficking remains irrelevant to the majority of victims in the UK. Instead, the challenge is continued survival and avoiding the revolving door back into exploitation.

Kate Roberts is Head of Office of the Human Trafficking Foundation. She has over 10 years' experience in anti-trafficking work, including with direct assistance and case work, as well as policy development. Kate has indepth knowledge of the UK's anti-trafficking and anti-slavery measures, having been a first responder to the UK's National Referral Mechanism from 2009 to 2016, and has used this experience to influence antitrafficking policy and to develop campaigns. She has given evidence at several parliamentary inquiries, including at all stages of the Modern Slavery Bill. Kate holds a BA in Social Anthropology with Development Studies from Sussex University, as well as an LLM in Human Rights from Birkbeck University, School of Law. Email: kate@humantraffickingfoundation.org

16 Report to a meeting of the All Party Parliamentary Group on Trafficking and Modern Slavery, November 2017.

17 For more information, see University of Liverpool, The Co-op's Bright Future Programme: An independent interim review, October 2017, $\quad$ retrieved $\quad 8 \quad$ March 2018 , https://assets.contentful.com/5ywmq66472jr/LZjcr3eQCscSOQgiUkieu/bba0597251a796fd3883f4f0e13b54b7/Brigh t Future Report.pdf.

18 Lord McColl of Dulwich, Modern Slavery (Victim Support) Bill [HL], House of Lords, 2017, retrieved 8 March 2018, https://publications.parliament.uk/pa/bills/lbill/2017-2019/0004/18004.pdf.

${ }^{19}$ See the minister of state's response to the Second Reading debate in House of Lords Hansard, 'Modern Slavery (Victim Support) Bill [HL]', 8 September 2017, below column 2245, retrieved 8 March 2018, https://hansard.parliament.uk/lords/2017-09-08/debates/C145B8B8-D46E-4F11-88C79C03081108C6/ModernSlavery(VictimSupport)Bill(HL). 